\title{
Bioindicator demonstrates high persistence of sulfentrazone in dry soil ${ }^{1}$
}

\author{
Renato Coradello Lourenço ${ }^{2}$, Saul Jorge Pinto de Carvalho
}

\section{ABSTRACT}

In sugarcane crop areas, the application of preemergence herbicides with long residual effect in the soil has been frequently necessary. The herbicide persistence in the soil must be high especially because of applications during the dry season of the year, after sugarcane harvest. This study aimed at estimating the sulfentrazone persistence and dissipation in dry soil using bioindicator. Five experiments were carried out, divided into two phases. In the first phase, three dose-response curves were adjusted to select the best bioindicator to be adopted in the second phase. Niger was adopted due to its lower sensibility to sulfentrazone. In the second phase, a new dose-response curve was carried out, with six doses of sulfentrazone, in order to standardize the bioindicator sensibility to sulfentrazone. At the end, another experiment with six periods of sulfentrazone persistence in dry clay soil was developed. Persistence periods were: 182 , 154, 125, 98 and 30 days. The bioindicator was seeded at the application day in treated plots and control. In this experiment, the sulfentrazone dose applied was $800 \mathrm{~g} \mathrm{ha}^{-1}$. Niger was considered a good species to estimate the sulfentrazone persistence in dry soil. The sulfentrazone phytotoxic activity was identified up to 182 days after application, and its average dissipation rate was $2.15 \mathrm{~g} \mathrm{ha}^{-1}$ day $^{-1}$, with half-life higher than 182 days.

KEY-WORDS: Saccharum spp.; Guizotia abyssinica Cass.; microbial degradation.

\section{INTRODUCTION}

In the last few decades, weed management in sugarcane (Saccharum spp.) crop has been based on herbicide applications, mostly recommended on pre-emergence or initial post-emergence. Therefore, most molecules are applied on the soil surface (Christoffoleti al. 2009). In areas where weeds must be controlled for a long time, which is the case for

\section{RESUMO}

Bioindicador demonstra alta

persistência de sulfrentrazone em solo seco

$\mathrm{Na}$ cultura da cana-de-açúcar, com frequência, temse a necessidade da aplicação de herbicidas pré-emergentes com longo efeito residual no solo. A persistência do herbicida no solo deve ser alta, principalmente devido a aplicações no período seco do ano, após a colheita da cultura. Objetivouse estimar a persistência e dissipação do sulfentrazone em solo seco, utilizando-se bioindicador. Foram realizados cinco experimentos, divididos em duas fases. $\mathrm{Na}$ primeira fase, três curvas de dose-resposta foram elaboradas para selecionar o melhor bioindicador a ser adotado na segunda fase. O niger foi selecionado devido à sua menor sensibilidade à molécula. $\mathrm{Na}$ segunda fase, realizou-se nova curva de dose-resposta com seis doses de sulfentrazone, padronizando a relação de sensibilidade do bioindicador à presença de sulfentrazone. Ao final, realizouse um experimento com seis períodos de persistência de sulfentrazone, em solo argiloso seco. Os períodos de persistência foram: 182, 154, 125, 98 e 30 dias. O bioindicador foi semeado no dia da aplicação, em parcelas tratadas e controle. Neste experimento, a dose de sulfentrazone foi fixada em $800 \mathrm{~g} \mathrm{ha}^{-1}$. O niger foi considerado como espécie adequada para estimar a persistência do sulfentrazone em solo seco. A atividade fitotóxica do sulfentrazone foi identificada até 182 dias após a aplicação e sua taxa média de dissipação foi de $2,15 \mathrm{~g} \mathrm{ha}^{-1} \mathrm{dia}^{-1}$, com meia vida superior a 182 dias.

PALAVRAS-CHAVE: Saccharum spp.; Guizotia abyssinica Cass.; degradação microbiana.

sugarcane crop, herbicides with long soil residual activity have been continuously adopted (Velini \& Negrisoli 2000, Carvalho et al. 2012).

In central and southern regions of Brazil, sugarcane harvest occurs throughout winter, making the dry season application of residual herbicides an excellent option for weed management (Azânia et al. 2006). Herbicides that have efficacy even if applied in dry season usually are not photodegradable, have 
low tendency to volatilization, high water solubility, low sorption to soil colloids and are mainly degraded by microbes (Christoffoleti et al. 2009, Carvalho et al. 2012).

Among diverse options of herbicides registered to sugarcane crop, sulfentrazone may be highlighted (Carvalho et al. 2012). In plants, this herbicide inhibits protoporphyrinogen oxidase (PROTOX), indirectly generating reactive oxygen $\left(\mathrm{O}^{-}\right)$within the cells. This free radical promotes membrane lipids peroxidation, rapidly leading cells to death (Carvalho \& López-Ovejero 2008). However, sulfentrazone is a weak acid with pKa of 6.56 and, in the soil, it is primarily found non-dissociated. Therefore, sulfentrazone solubility is influenced by $\mathrm{pH}$, varying between $110 \mathrm{mg} \mathrm{L}^{-1}(\mathrm{pH} \mathrm{6.0)}$ and $1,600 \mathrm{mg} \mathrm{L}^{-1}(\mathrm{pH} 7.5)$. The sulfentrazone $\log \mathrm{K}_{\text {ow }}$ is 1.48 (FMC Corp. 1995, Christoffoleti et al. 2009, Rodrigues \& Almeida 2011).

According to Blanco et al. (2010), sugarcane is one of the crops that have the highest risks of problems regarding herbicide-soil persistence, which may cause environmental contamination and toxicity to sensitive crops grown in succession. After application, herbicides undergo several processes until their complete degradation. In general, soil is recognized as the final destiny of most of the herbicide molecules (Law 2001). In the soil, herbicides may be absorbed by plants or undergo soil sorption, lixiviation or degradation through physical, chemical or biological processes (Silva et al. 2007). The behavior and fate of herbicides in the environment are directly related to their molecular structure and physico-chemical properties, as well as to environmental conditions (temperature, soil moisture and type, rainfall, organic matter and application form) (Gebler \& Spadotto 2004).

Among factors interfering on herbicide presence at the environment, soil moisture must be highlighted. Rainfall frequency and intensity are important factors that influence the activity of a residual herbicide. Soil moisture interferes on the chemical and biological processes responsible for herbicide dissipation at the environment (Silva et al. 1999). The amount of water, from rain or irrigation, applied in the area after herbicide spraying affects molecule distribution, movement, persistence and efficacy, as well as crop tolerance to the herbicide (Ogg Júnior \& Dowler 1988).
Frequently, complex techniques are adopted for estimating pesticide persistence in the environment, involving chromatography (liquid or gas), radiolabeled molecules or stable isotopes, with high cost of execution. Blanco et al. (2010) emphasize that the bioactivity period of a molecule in the soil can also be evaluated by biological methods, using an herbicide-sensitive plant, known as bioindicator or test plant. Bioindicators may be used to evaluate the environmental impact, as well as to estimate the persistence time of an herbicide in the soil.

Therefore, this study aimed at estimating sulfentrazone persistence and dissipation, in a dry soil with bioindicator plants.

\section{MATERIAL AND METHODS}

The experiment was conducted at the Instituto Federal de Educação, Ciência e Tecnologia do Sul de Minas Gerais, in Machado (21 ${ }^{\circ} 40^{\prime} \mathrm{S}, 45^{\circ} 55^{\prime} \mathrm{W}$ and $850 \mathrm{~m}$ of altitude), Minas Gerais State, Brazil, between September 2013 and April 2014. Five experiments were divided into two phases: three in the first phase and two in the second one. In all trials, plots consisted of 1.0 L punctured plastic pots filled with dried and sieved clay soil (Table 1) collected from the surface layer (0-0.10 m) of a dystrophic Oxisol.

In the first phase, the experiments aimed at identifying the best bioindicator for sulfentrazone pre-emergence applications. Three independent trials were performed, one for each plant species. The following species were evaluated as bioindicators: rapeseed (Brassica napus L.), niger (Guizotia abyssinica Cass.) and millet (Panicum miliaceum L.). Dose-response curves were developed for evaluating herbicide-sensitivity of each species. The experiments were installed in a complete randomized blocks design, with six sulfentrazone doses $\left(3,200 \mathrm{~g} \mathrm{ha}^{-1}\right.$, $800 \mathrm{~g} \mathrm{ha}^{-1}, 200 \mathrm{~g} \mathrm{ha}^{-1}, 50 \mathrm{~g} \mathrm{ha}^{-1}, 12.5 \mathrm{~g} \mathrm{ha}^{-1}$ and herbicide absence) and four replications, totaling 24 plots species $^{-1}$. After pre-emergence herbicide application, bioindicators were seeded with $1.6 \mathrm{~g}$ of seeds per pot and then covered with a thin layer of soil. In the nursery, all plots were irrigated daily.

In the second phase, two simultaneous experiments were performed: one with different doses of sulfentrazone, to adjust a dose-response curve, and another with different periods of sulfentrazone persistence in the soil. The interpolation of the results from these experiments allowed to estimate the 
Table 1. Physical and chemical characterization of the soil used in the experiments ${ }^{1}$ (Machado, Minas Gerais State, Brazil, 2013).

\begin{tabular}{lcr}
\hline \multicolumn{1}{c}{ Parameter } & Unity & Analysis \\
\hline $\mathrm{pH}$ & & 5.30 \\
Organic matter & $\mathrm{g} \mathrm{kg}^{-1}$ & 19.30 \\
Phosphorous & $\mathrm{mg} \mathrm{dm}^{-3}$ & 36.30 \\
Potassium & $\mathrm{mg} \mathrm{dm}^{-3}$ & 133.30 \\
Calcium & $\mathrm{mmol}_{\mathrm{c}} \mathrm{dm}^{-3}$ & 24.30 \\
Magnesium & $\mathrm{mmol}_{\mathrm{c} \mathrm{dm}^{-3}}$ & 7.10 \\
Aluminum & $\mathrm{mmol}_{\mathrm{c}} \mathrm{dm}^{-3}$ & 1.00 \\
$\mathrm{H}+\mathrm{Al}$ & $\mathrm{mmol}_{\mathrm{c}} \mathrm{dm}^{-3}$ & 36.00 \\
Sum of bases & $\mathrm{mmol}_{\mathrm{c}} \mathrm{dm}^{-3}$ & 35.00 \\
Saturation by aluminum & $\%$ & 3.00 \\
Cation exchange capacity & $\mathrm{cmol}_{\mathrm{c}} \mathrm{dm}^{-3}$ & 71.00 \\
Saturation of bases (V $\%)$ & $\%$ & 49.30 \\
Cuprum & $\mathrm{mg} \mathrm{dm}^{-3}$ & 1.20 \\
Iron & $\mathrm{mg} \mathrm{dm}^{-3}$ & 53.30 \\
Manganese & $\mathrm{mg} \mathrm{dm}^{-3}$ & 22.00 \\
Zinc & $\mathrm{mg} \mathrm{dm}^{-3}$ & 10.90 \\
Boron & $\mathrm{mg} \mathrm{dm}^{-3}$ & 0.38 \\
Total sand & $\mathrm{g} \mathrm{dm}^{-3}$ & 470.00 \\
Clay & $\mathrm{g} \mathrm{dm}^{-3}$ & 400.00 \\
Silt & $\mathrm{g} \mathrm{dm}^{-3}$ & 130.00 \\
Textural class & & Clay \\
\hline
\end{tabular}

${ }^{1}$ Average of three samples.

molecule dissipation at the environment. The doseresponse curve was obtained with the bioindicator selected in the first phase, with the same rates and six replicates. Regression curves were adjusted between sulfentrazone dose and bioindicator control or between sulfentrazone dose and bioindicator mass of dry matter.

A persistence experiment was installed using a randomized blocks design, with seven treatments and eight replicates, totaling 56 plots. Treatments consisted of different periods of sulfentrazone persistence in dry soil and control plots without herbicide application. Time-spaced applications were carried out at different dates, so the effective installation at nursery occurred in the same day, at the end of the period. Pre-emergence sulfentrazone applications were performed on: 09/11/2013 (182 days before seeding - DBS), 10/09/2013 (154 DBS), 11/07/2013 (125 DBS), 12/04/2013 (98 DBS), 02/10/2014 (30 DBS) and 03/12/2014 (0 DBS). In this trial, the sulfentrazone rate was fixed at $800 \mathrm{~g} \mathrm{ha}^{-1}$, according to the product label recommendation.

After each pre-emergence application, pots were kept dry at the laboratory, at room temperature and in a dry place, without stacking or soil revolving, however, with indirect incidence of sunlight. At the time of the experiment installation (03/12/2014), the bioindicator selected in the first phase was seeded as in the previous experiments. Pots were transported and allocated to a non-protected nursery, where they were irrigated daily. Both second phase experiments were allocated side by side, allowing analyses of sulfentrazone dose-response and persistence in the soil.

Applications were performed using an experimental backpack sprayer pressurized by $\mathrm{CO}_{2}$. Only one flat fan nozzle was used (XR 110.02), distanced at $0.5 \mathrm{~m}$ above the target and calibrated for spraying of $200 \mathrm{~L} \mathrm{ha}^{-1}$. Bioindicator percentage control was evaluated at 14 and 28 days after seeding (DAS). At 28 DAS, bioindicator residual mass was also evaluated. For control evaluations, a $0-100 \%$ percentage scale was considered, where zero represents the absence of symptoms and $100 \%$ the plant death (SBCPD 1995). Plant dry masses were obtained by harvesting all the remaining shoot material in the plots, with subsequent drying in an oven at $70{ }^{\circ} \mathrm{C}$, for 72 hours. Dry mass values were corrected to percentage by comparing the residual mass of each herbicide-applied plot to the mass of the control plots (herbicide absence), considered as $100 \%$.

For each experiment, data were submitted to analysis of variance at $5 \%$. When the $\mathrm{F}$ value was significant, the rate-response curves were obtained using the non-linear log-logistic model adapted by Carvalho et al. (2010):

$$
y=\frac{100}{\left[1+\left(\frac{x}{L D_{50}}\right)^{\alpha}\right]}
$$

where: $y=$ percentage of control or residual dry matter; $x=$ herbicide dose $\left(\mathrm{g} \mathrm{ha}^{-1}\right) ; L D_{50}=$ sulfentrazone dose that reaches $50 \%$ of response (control or mass reduction); and $\alpha=$ slope of the curve. For the second phase experiment, focusing on agronomic efficacy, $L D_{80}$ was also calculated, i.e., the necessary dose to reach $80 \%$ of control or to reduce dry matter by $80 \%$.

For the persistence experiment, regression analysis was adjusted using polynomial models. Having both regressions (dose and time), it was possible to do a data interpolation, adjusting final 
regression to the equation $y=a x+b$. Control values or bioindicator residual mass obtained after different periods of sulfentrazone soil persistence were corrected to their proportional dose $\left(\mathrm{g} \mathrm{ha}^{-1}\right)$, using the bioindicator standard sensibility curve. In short, it was possible to estimate the daily dissipation rate of active ingredient, after sulfentrazone application on dry soil.

\section{RESULTS AND DISCUSSION}

Sulfentrazone susceptibility of the three tested species was fit with dose-response curves, with high coefficients of determination (Table 2). Rapeseed and millet were characterized as extremely sensitive to sulfentrazone, with $L D_{50}$ always below $50 \mathrm{~g} \mathrm{ha}^{-1}$, which is equivalent to $1 / 16$ of the commercial recommendation $\left(800 \mathrm{~g} \mathrm{ha}^{-1}\right)$. Niger was the least sensitive species to sulfentrazone, with a mean $L D_{50}$ of $236 \mathrm{~g} \mathrm{ha}^{-1}$ (Table 2).

In general, seeds had low germination under higher sulfentrazone doses. When germinated, plants became yellow, with necrosis progressing to seedling death. In order to evaluate sulfentrazone persistence, the least sensitive bioindicator (niger) was chosen. The hypothesis is that highly sensitive bioindicators (rapeseed and millet) would be easily controlled by sulfentrazone, even after 180 days of environmental persistence, making it difficult to estimate the soil residual rate. Thus, niger was the bioindicator chosen for the second phase of the experiment.

In the second phase, a log-logistic model was also used to fit the niger susceptibility to

Table 2. Statistical parameters ${ }^{1}$ for adjusting bioindicator control and percentage dry mass after application of different sulfentrazone doses, at 14 and 28 days after seeding (DAS) (Machado, Minas Gerais State, Brazil, 2013).

\begin{tabular}{llrrr}
\hline \multirow{2}{*}{ Bioindicator } & \multicolumn{2}{c}{ Variable } & \multicolumn{3}{c}{ Statistical parameter } \\
\cline { 3 - 5 } & & $\mathrm{LD}_{50}$ & \multicolumn{1}{c}{$\alpha$} & \multicolumn{1}{c}{$\mathrm{R}^{2}$} \\
\hline \multirow{3}{*}{ Rapeseed } & Control at 14 DAS & 30.373 & -1.574 & 0.998 \\
& Control at 28 DAS & 33.433 & -1.348 & 0.995 \\
& Percentage dry mass & 47.966 & 1.220 & 0.999 \\
\hline \multirow{3}{*}{ Niger } & Control at 14 DAS & 217.764 & -2.554 & 0.999 \\
& Control at 28 DAS & 219.143 & -2.812 & 0.999 \\
& Percentage dry mass & 273.335 & 3.200 & 0.999 \\
\hline \multirow{3}{*}{ Millet } & Control at 14 DAS & 32.184 & -2.026 & 0.999 \\
& Control at 28 DAS & 38.690 & -3.207 & 0.999 \\
& Percentage dry mass & 44.020 & 4.332 & 0.999 \\
\hline
\end{tabular}

${ }^{1}$ Mathematical model: $y=100 /\left(1+\left(x / \mathrm{LD}_{50}\right)^{\alpha}\right) ; \mathrm{LD}_{50}=$ dose of active ingredient that promotes $50 \%$ of control or dry mass reduction; $\alpha=$ curve slope; $\mathrm{R}^{2}=$ coefficient of determination. sulfentrazone, with high coefficients of determination (Table 3). The mean value of $L D_{50}$ was $240 \mathrm{~g} \mathrm{ha}^{-1}$, similar to the values found in the first phase. For the second phase, niger $L D_{80}$ values were also measured, and were always below sulfentrazone commercial rates of $800 \mathrm{~g} \mathrm{ha}^{-1}$. Thus, it was possible to establish a niger sulfentrazone-susceptibility standard curve in a clay soil (Table 1) by measuring bioindicator control at 14 and 28 DAS, as well as mass of dry matter (Table 3). Working with the bioindicator Sorghum vulgare, Vivian et al. (2006) also obtained proper fit of dry mass to sulfentrazone rates using logistic equation.

Considering the bioindicator full (100\%) control, reached when it was seeded at the application day, a model was created correlating the efficacy loss with increasing periods of herbicide persistence in dry soil (Figure 1). At 14 DAS, the herbicide controlled $93 \%$ of bioindicator, when seeded at the application day. After 180 days of herbicide-soil persistence, $81 \%$ of control was reached. At $28 \mathrm{DAS}$, a higher loss of control efficacy was observed. The loss of herbicide efficacy was also observed with the dry matter of niger. However, even at 28 DAS, sulfentrazone high biological activity was observed, and control values greater than $70 \%$ and residual dry matter under $20 \%$ were found (Figure 1). Soil was kept dry all over the herbicide-soil persistence period. The results could be different if soil had been submitted to different standards of moisture.

Blanco et al. (2010) also observed that sulfentrazone persistence in soil is long and proportional to the initial applied dose. When sulfentrazone was applied at $600 \mathrm{~g} \mathrm{ha}^{-1}$, it could be detected until 601 days after application. When authors adopted 1,200 $\mathrm{g} \mathrm{ha}^{-1}$, molecules persisted in soil up to the end of the experiments, which was

Table 3. Statistical parameters ${ }^{1}$ for adjusting the niger control and percentage dry mass after the application of different sulfentrazone doses, at 14 and 28 days after seeding (DAS) (Machado, Minas Gerais State, Brazil, 2014).

\begin{tabular}{lcccc}
\hline \multirow{2}{*}{ Variable } & \multicolumn{4}{c}{ Statistical parameter } \\
\cline { 2 - 5 } & $\mathrm{LD}_{50}$ & $\alpha$ & $\mathrm{R}^{2}$ & $\mathrm{LD}_{80}$ \\
\hline Control at 14 DAS & 250.876 & -1.983 & 0.999 & 504.742 \\
Control at 28 DAS & 250.957 & -2.152 & 0.999 & 477.933 \\
Percentage dry mass & 218.515 & 2.195 & 0.989 & 410.930 \\
\hline
\end{tabular}

Mathematical model: $y=100 /\left(1+\left(x / \mathrm{LD}_{50}\right)^{a}\right)$; $\mathrm{LD}_{50}=$ dose of active ingredient that promotes $50 \%$ of control or reduction of dry matter; $\mathrm{LD}_{80}=$ dose of active ingredient that promotes $80 \%$ of control or reduction of dry matter; $\alpha=$ curve slope; $\mathrm{R}^{2}=$ coefficient of determination. 
superior to 704 days. Similarly, Vivian et al. (2006), using $S$. vulgare as bioindicator, observed biological activity of sulfentrazone in soil at 467 days after the application of $900 \mathrm{~g} \mathrm{ha}^{-1}$. These authors noticed a low molecule leaching potential, as residues remained on the soil upper layer $(0-0.10 \mathrm{~m})$. Carvalho et al. (2012) also observed sulfentrazone high biological activity in the soil at 130 days after application. These authors pointed out that the sulfentrazone herbicide has positive properties for soil application in dry seasons, such as high solubility, low $\mathrm{K}_{\mathrm{ow}}$ and low photodegradation.
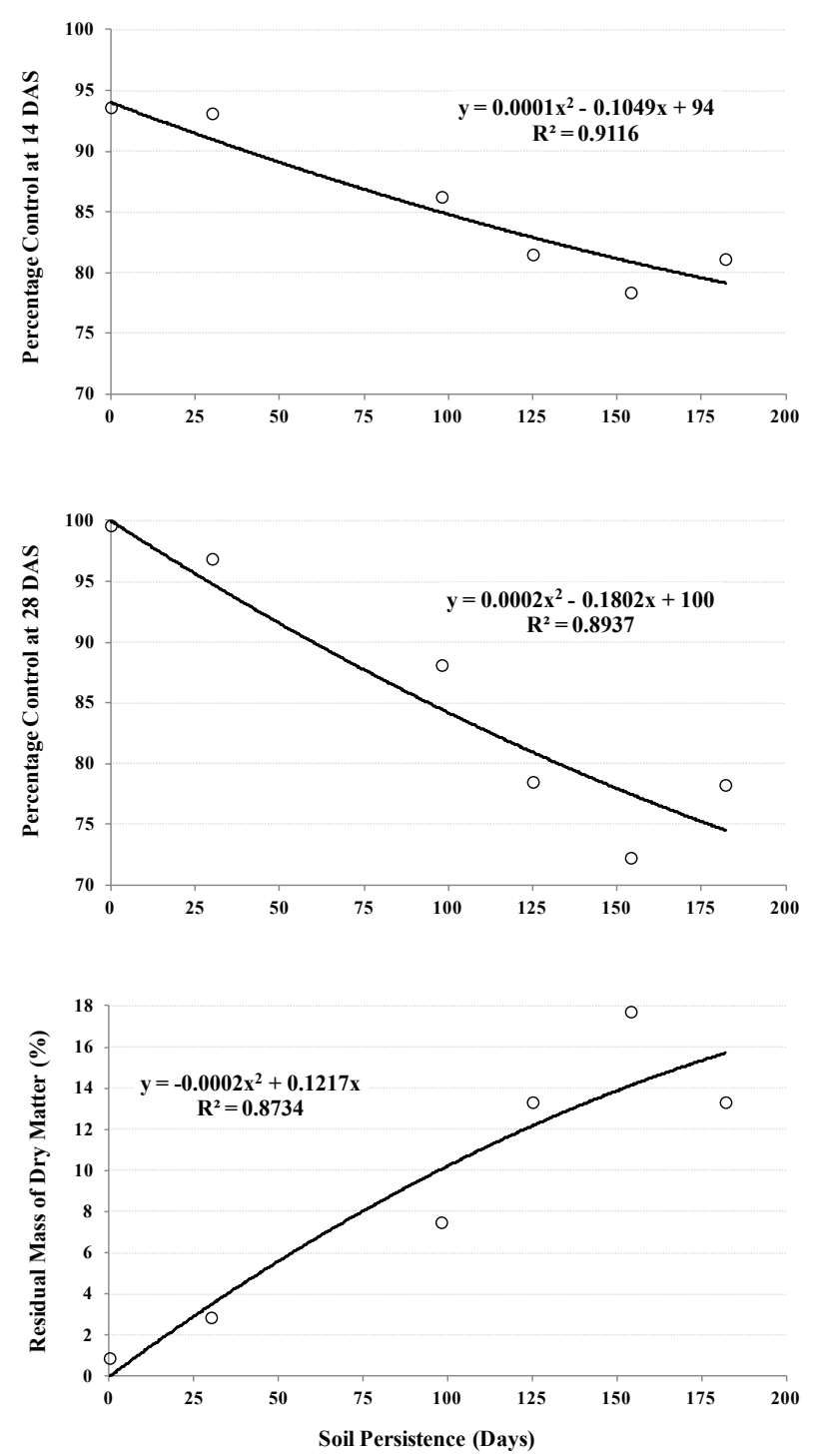

Figure 1. Percentage control of niger at 14 and 28 days after seeding (DAS), as well as percentage mass of dry matter after persistence of sulfentrazone in dry clay soil (Machado, Minas Gerais State, Brazil, 2014).
Herbicide dissipation in soil occurs through different processes and with distinct speeds, influenced by molecule physical-chemical properties, soil attributes, microbiological activity, environmental conditions and by the interaction of these factors (Vivian et al. 2006, Christoffoleti et al. 2009). However, in the case of sulfentrazone, some authors suggest that the sorption potential of this herbicide is related to the soil type, influenced by organic matter content and $\mathrm{pH}$ (Brusseau \& Rao 1989, Grey et al. 1997, Melo et al. 2010, Freitas et al. 2014).

Dose-control and time-control interpolation allows to estimate the remaining of sulfentrazone amount in soil (dose-time) with bioindicator. Persistence lines were corrected to the intersection point of $800 \mathrm{~g} \mathrm{ha}^{-1}$, which was the starting rate (Figure 2). Frequently, non-linear or sigmoid models are used to analyze herbicide dissipation in the environment. However, in this study, a linear fit was adequate and facilitated data discussion. Possibly, with longer periods of soil persistence above 180 days, data distribution could be different, resulting in non-linear models data fit. Thus, the equation adopted was $y=-a x+800$. In this case, the $a$ parameter has become an estimate of the sulfentrazone daily dissipation rate in dry soil. Dissipation was proportional to $1.72 \mathrm{~g} \mathrm{ha}^{-1}$ day $^{-1}$ at $14 \mathrm{DAS}$ and $2.22 \mathrm{~g} \mathrm{ha}^{-1} \mathrm{day}^{-1}$ at $28 \mathrm{DAS}$, while for mass of dry matter it was $2.08 \mathrm{~g} \mathrm{ha}^{-1}$ day $^{-1}$ (Figure 2).

The results present on Table 3 and Figures 1 and 2 are consistent. For example, in Figure 1, at $14 \mathrm{DAS}, 80 \%$ of control $\left(L D_{80}\right)$ was reached with 182 days of sulfentrazone-soil persistence. In Table 3, $504.7 \mathrm{~g} \mathrm{ha}^{-1}$ of sulfentrazone was necessary for reaching $L D_{80}$, being consistent with Figure 2, which records a dose close to $500 \mathrm{~g} \mathrm{ha}^{-1}$ for the same period of persistence, at 14 DAS.

Evaluations carried out at 28 DAS have even greater experimental relevance, because they were reached after full stabilization of the results and contain a subjective (control) and an objective variable (dry matter). Therefore, considering the average of the two variables measured at 28 DAS, the sulfentrazone soil dissipation rate was $2.15 \mathrm{~g} \mathrm{ha}^{-1} \mathrm{day}^{-1}$. Sulfentrazone dissipation half-life $\left(t_{1 / 2}\right)$ in dry soil was not fully reached, thus $t_{1 / 2}$ might be considered superior to 182 days. This is an important information and justifies the 

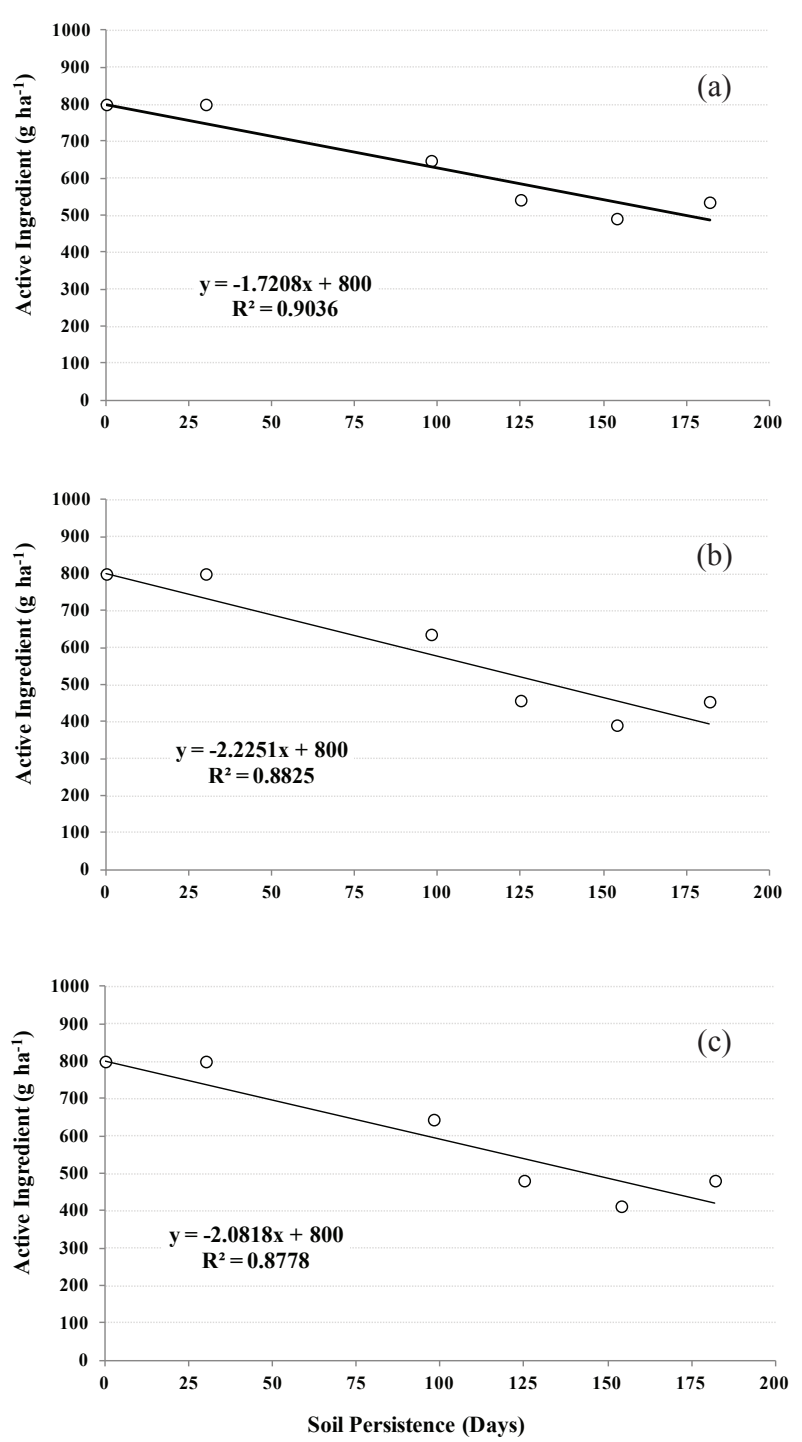

Figure 2. Proportional losses of sulfentrazone $\left(\mathrm{g} \mathrm{ha}^{-1}\right)$ after periods of persistence in dry clay soil, estimated by bioindicator at 14 (a) and 28 (b) days after seeding, as well as residual dry matter of bioindicator (c) (Machado, Minas Gerais State, Brazil, 2014).

common use of sulfentrazone in sugarcane crop, where pre-emergence herbicide should remain in the soil upper layer for a long time, even in dry winter.

Martinez et al. (2010) have found $t_{1 / 2}$ of 91.6 days for sulfentrazone, in soil incubated at $40{ }^{\circ} \mathrm{C}$ with $70 \%$ of field capacity. They reported that higher incubation temperatures $\left(30-40{ }^{\circ} \mathrm{C}\right)$ accelerate molecule degradation, but no effect of soil moisture was found. Brum et al. (2013), in turn, found out variable values of sulfentrazone $\mathrm{t}_{1 / 2}$ ranging between 34 and 116 days, in different experimental conditions. These authors concluded that soil moisture and incubation temperature influence herbicide persistence, whose degradation occurred more quickly in moist soil ( $80 \%$ of field capacity) and under high temperature $\left(40^{\circ} \mathrm{C}\right)$. Therefore, sulfentrazone dissipation at the environment is suggested to occur primarily by microbial degradation (Ohmes et al. 2000, Martinez et al. 2010, Rodrigues \& Almeida 2011, Brum et al. 2013).

Biodegradation is considered the main mechanism of herbicide degradation on the ground, although its contribution varies widely among products (Moreira \& Siqueira 2006). In general, increasing soil moisture to field capacity stimulates microbial activity (Guimarães 1992). Soil available water has a crucial role in the effectiveness of residual herbicides, and for sulfentrazone it was not different, because in addition to affecting microorganism activity and molecule absorption by plants, soil moisture also influences molecule behavior at the interface with soil components. Moisture reduction also decreases free spaces for herbicides in soil solution. Under these conditions, smaller quantities of product are bioavailable due to increased sorption. In dry soils, many microorganisms pass to dormant stage or become inactive, reducing significantly the rates of degradation (Christoffoleti et al. 2009, Carvalho et al. 2012).

In general, the use of bioindicator was an effective alternative for estimating sulfentrazone persistence in dry soil, especially with niger. Sulfentrazone half-life of dissipation was grater than the total duration of the experiment (182 days). High persistente may have been favoured by spraying the molecule over dry soil, with low microbial activity.

\section{CONCLUSIONS}

1. Niger (Guizotia abyssinica Cass.) is a good alternative of bioindicator species to estimate sulfentrazone persistence in dry soil.

2. Sulfentrazone phytotoxic activity occurs at least until 182 days after application, possibly favored by molecule spraying on dry soil with low microbial activity.

3. Sulfentrazone average dissipation rate was $2.15 \mathrm{~g} \mathrm{ha}^{-1}$ day $^{-1}$ and half-life of dissipation was superior to 182 days. 


\section{ACKNOWLEDGMENTS}

The authors would like to thank the Instituto Federal de Educação, Ciência e Tecnologia do Sul de Minas Gerais, especially Machado Campus, for contributing to the development of this study.

\section{REFERENCES}

AZÂNIA, C. A. M. et al. Seletividade de herbicidas: III Aplicação de herbicidas em pós-emergência inicial e tardia da cana-de-açúcar na época da estiagem. Planta Daninha, Viçosa, v. 24, n. 3, p. 489-495, 2006.

BLANCO, F. M. G.; VELINI, E. D.; BATISTA FILHO, A. Persistência do herbicida sulfentrazone em solo cultivado com cana-de-açúcar. Bragantia, Campinas, v. 69, n. 1, p. 71-75, 2010.

BRUM, C. S.; FRANCO, A. A.; SCORZA JÚNIOR, R. P. Degradação do herbicida sulfentrazone em dois solos de Mato Grosso do Sul. Revista Brasileira de Engenharia Agrícola e Ambental, Campina Grande, v. 17, n. 5, p. 558564, 2013.

BRUSSEAU, M. L.; RAO, P. S. C. The influence of sorbate organic matter interactions in sorption nonequilibrium. Chemosphere, Oxford, v. 17, n. 9-10, p. 1691-1706, 1989.

CARVALHO, S. J. P. et al. Adição simultânea de sulfato de amônio e ureia à calda de pulverização do herbicida glyphosate. Planta Daninha, Viçosa, v. 28, n. 3, p. 575584, 2010.

CARVALHO, S. J. P. et al. Atividade residual de seis herbicidas aplicados ao solo em época seca. Revista Ceres, Viçosa, v. 59, n. 2, p. 278-285, 2012.

CARVALHO, S. J. P.; LÓPEZ-OVEJERO, R. F. Resistência de plantas daninhas aos herbicidas inibidores da PROTOX (Grupo E). In: CHRISTOFFOLETI, P. J. (Coord.). Aspectos de resistência de plantas daninhas a herbicidas. Piracicaba: HRAC-BR, 2008. p. 69-77.

CHRISTOFFOLETI, P. J. et al. Comportamento dos herbicidas aplicados ao solo na cultura da cana-deaçúcar. Piracicaba: CP 2, 2009.

FMC Corp. Technical bulletin of sulfentrazone. Philadelphia: FMC Corp., 1995.

FREITAS, M. A. M. et al. Sorção do sulfentrazone em diferentes tipos de solo determinada por bioensaios. Planta Daninha, Viçosa, v. 32, n. 2, p. 385-392, 2014.

GEBLER, L.; SPADOTTO, C. A. Comportamento ambiental de herbicidas. In: VARGAS, L.; ROMAN, E. S. (Eds.). Manual de manejo e controle de plantas daninhas. Bento Gonçalves: Embrapa Uva e Vinho, 2004. p. 57-87.
GREY, T. L. et al. Sulfentrazone adsorption and mobility as affected by soil and $\mathrm{pH}$. Weed Science, Lawrence, v. 45, n. 5, p. 733-738, 1997.

GUIMARÃES, G. L. Impactos ecológicos do uso de herbicidas. In: SIMPÓSIO NACIONAL SOBRE MANEJO INTEGRADO DE PLANTAS DANINHAS EM HORTALIÇAS, 1., 1992, Botucatu. Anais... Botucatu: Unesp, 1992. p. 121-141.

LAW, S. E. Agricultural electrostatic spray application: a review of significant research and development during de 20th century. Journal of Electrostatics, Cleveland, v. 5152, n. 1, p. 25-42, 2001.

MARTINEZ, C. O. et al. Microbial degradation of sulfentrazone in Brazilian Rhodic Hapludox soil. Brazilian Journal of Microbiology, São Paulo, v. 41, n. 1, p. 209217, 2010.

MELO, C. A. D. et al. Efeito residual de sulfentrazone, isoxaflutole e oxyfluorfen em três solos. Planta Daninha, Viçosa, v. 28, n. 4, p. 835-842, 2010.

MOREIRA, F. M. S.; SIQUEIRA, J. O. Microbiologia e bioquímica do solo. Lavras: UFLa, 2006.

OGG JÚNIOR, A. G.; DOWLER, C. C. Applying herbicides through irrigation systems. In: McWORTHER, C. G.; GEBHARDT, M. R. (Eds.). Methods of applying herbicides. Champaign: WSSA, 1988. p. 145-164.

OHMES, G. A.; HAYES, R. M.; MUELLER, T. C. Sulfentrazone dissipation in a Tennessee soil. Weed Technology, Lawrence, v. 14, n. 1, p. 100-105, 2000.

RODRIGUES, B. N.; ALMEIDA, F. S. Guia de herbicidas. 5. ed. Londrina: Ed. dos Autores, 2011.

SILVA, A. A. et al. Herbicidas: comportamento no solo. In: SILVA, A. A.; SILVA, J. F. (Eds.). Tópicos em manejo de plantas daninhas. Viçosa: Universidade Federal de Viçosa, 2007. p. 189-248.

SILVA, A. A. et al. Persistência de herbicidas do grupo das imidazolinonas e efeitos sobre as culturas sucessoras de milho e sorgo. Acta Scientiarum, Maringá, v. 21, n. 3, p. 459-465, 1999.

SOCIEDADE BRASILEIRA DA CIÊNCIA DAS PLANTAS DANINHAS (SBCPD). Procedimentos para instalação, avaliação e análise de experimentos com herbicidas. Londrina: SBCPD, 1995.

VELINI, E. D; NEGRISOLI, E. Controle de plantas daninhas em cana crua. In: CONGRESSO BRASILEIRO DA CIÊNCIA DAS PLANTAS DANINHAS, 22., 2000, Foz do Iguaçu. Anais... Foz do Iguaçu: SBCPD, 2000. p. $148-164$.

VIVIAN, R. et al. Persistência de sulfentrazone em Argissolo Vermelho-Amarelo cultivado com cana-deaçúcar. Planta Daninha, Viçosa, v. 24, n. 4, p. 741-750, 2006. 